\title{
Political discourse on higher education in Denmark from enlightened citizen to homo economicus
}

Vingaard Johansen, Ulrik ; Knudsen, Frederik B.; Engelbrecht Kristoffersen, Christian; Rasmussen, Joakim Stellfeld; Saaby Steffen, Emil; Sund, Kristian J.

Published in:

Studies in Higher Education

DOI:

10.1080/03075079.2015.1045477

Publication date:

2017

Document Version

Peer reviewed version

Citation for published version (APA):

Vingaard Johansen, U., Knudsen, F. B., Engelbrecht Kristoffersen, C., Rasmussen, J. S., Saaby Steffen, E., \& Sund, K. J. (2017). Political discourse on higher education in Denmark: from enlightened citizen to homo economicus. Studies in Higher Education, 42(2), 264-277. https://doi.org/10.1080/03075079.2015.1045477

\section{General rights}

Copyright and moral rights for the publications made accessible in the public portal are retained by the authors and/or other copyright owners and it is a condition of accessing publications that users recognise and abide by the legal requirements associated with these rights.

- Users may download and print one copy of any publication from the public portal for the purpose of private study or research.

- You may not further distribute the material or use it for any profit-making activity or commercial gain.

- You may freely distribute the URL identifying the publication in the public portal.

Take down policy

If you believe that this document breaches copyright please contact rucforsk@kb.dk providing details, and we will remove access to the work immediately and investigate your claim. 
RESEARCH ARTICLE (pre-publication version)

\section{Please cite as:}

Ulrik Vingaard Johansen, Frederik B. Knudsen, Christian Engelbrecht Kristoffersen, Joakim Stellfeld Rasmussen, Emil Saaby Steffen \& Kristian J. Sund (2015): Political discourse on higher education in Denmark: from enlightened citizen to homo economicus, Studies in Higher Education, DOI:

10.1080/03075079.2015.1045477

Political Discourse on Higher Education in Denmark: from Enlightened Citizen to Homo Economicus

Ulrik Vingaard Johansen

Frederik B. Knudsen

Christian Engelbrecht Kristoffersen

Joakim Stellfeld Rasmussen

Emil Saaby Steffen

Kristian J. Sund*

Department of Communication, Business and Information Technologies

Roskilde University

Universitetsvej 1

4000 Roskilde

Denmark

*Corresponding author. Email: sund@ ruc.dk 


\begin{abstract}
The literature on higher education policy points to changes in the dominant discourse over the years. In particular, the ascendance of a discourse marked by concepts of new public management, using language inspired by neoclassical economic theory which characterizes education as a marketplace where students are customers, has led scholars to critically question the foundations of modern higher education policy. This paper uses critical discourse analysis to trace the development of higher education policy discourse in Denmark from the late 1970s until today. We find that the discourse has moved from a pluralistic one embracing not only the economic benefits of education, but also emphasizing on democracy, citizenship and equality, towards a predominantly economic one, focussed squarely on notions of globalisation and competitiveness in a knowledge society.
\end{abstract}

\title{
Keywords
}

Discourse analysis; Educational policy; Europe; Globalisation; Policy Analysis

\section{Introduction}

The study of policy change in the educational sector has largely been centred on structural and actor approaches, but alternative perspectives have emerged in the recent literature (Saarinen \& Ursin, 2012). One of these emerging approaches is the discursive view on policy change, where the main focus is on how policies are constructed through policy texts. Higher education policy discourse is largely influenced by general economic policy, and by the perceived role that higher education can play in society. This role has changed over the last few decades, notably within the European Union, where the Bologna process has contributed to a discourse based on concepts such as globalization, knowledge economy, mobility or information revolution (Keeling, 2006). The increased focus on knowledge, research and innovation has led to a shift in the social role of universities towards being seen by policymakers as an engine for the production of knowledge, and for national competitiveness in a globalized world. The concept of knowledge economy, or knowledge society have been key in this transformation, during which both the role of universities (Välimaa \& Hoffman, 2008), and of students (Leathwood \& O'Connell, 2003), have been redefined. Tracing this transformation not only as a change in government action, but as a change in discourse, can help explain why and how the transformation is taking place.

Successive Danish governments have increased their focus on education as an investment in human capital. This strategy is meant to secure Denmark's position on the global market as a knowledge-based economy with a big service sector. Accompanying this, recent reforms have introduced new public management ideas in the governance model and the organization of higher education institutions, similar to the increased managerialism witnessed almost a decade earlier in the UK (Deem \& Brehony, 2005; Trowler, 2001). It thus appears clear in the Danish case, that policy language not only describes policy actions, but also creates and supports them, by emphasizing some goals, and leaving aside others (Saarinen, 2008a; Fairclough, 1993). Whilst the value of studying policy documents from a discursive perspective has been pointed out in the literature, few published studies have actually conducted such analysis (Tight, 2003; Saarinen, 2008a), and even less have attempted a longer term historical analysis of the changing higher education policy discourse. 
The purpose of this study is to examine the role played by economic rationales in the formulation of Danish education policy since 1978. We use a method of critical discourse analysis on seven different policy plans which deal with the objectives of education. The study analyses policy plans from the Danish Ministry of Science, Innovation, and Higher Education, the Ministry of Education, and the Ministry of Finance. We focus on the top-level government policies and changes to these over time, rather than on the outcomes of specific policies. Thereby we refrain from judging the successes or failures of different educational policies and merely trace the overall discursive changes. We employ a methodology inspired by Jäger $(1993 ; 2001)$ in which the education policy plans represent the hegemonic education discourse, as the government exercises executive power in this area. The analysis identifies and traces five thematic strings in each of the plans. The themes identified are economic rationales, individualisation, global competition, democracy and citizenship, and equality. We conclude that in the earlier plans democracy, citizenship and equality play a more prominent role, whereas in newer plans the predominant strings are individualization, global competition, and economic rationales. Furthermore the newer plans are characterized by an entanglement of the strings so that individualization, globalization, and economic rationales complement each other. This entanglement can be described as a marketization of the general educational discourse (Fairclough, 1993; Land, 2004; Olssen \& Peters, 2005).

\section{Literature}

European higher education policy, both at the European Union level, and at the level of individual nations, has been widely discussed in the literature. There has been some debate about the wider social context within which the current texts are anchored, particularly focused on the somewhat controversial labels used in policy documents, such as the notion of knowledge society, and a general perceived move towards neoliberalism (Olssen \& Peters, 2005). One way to approach this discussion is through the use of some form of discourse analysis. By discourse we mean language as a social practice, conditioned by existing social structures, such that the text, whether spoken, written, or otherwise presented, is relative to and formed by social practices (Giddens, 1984).

One of the key contributions of discourse analysis is that it enables the researcher to critically identify not only what is present in the text, but also to uncover that which is absent. By recognizing that texts are constructed by individuals deeply embedded in social practice, and that it is these practices that systematically form, define and re-define the objects of the text, which in turn serves as a further guide to practice, it becomes possible to entertain the notion that the accepted social reality is not the only possible reality (Foucault, 1972), and may be explained as a social construction. In the context of higher education policy, policy texts do not merely describe policies that are implemented, but reveal what problems, goals and agendas are brought to the fore, and just as importantly, which are left aside (Saarinen, 2008a).

The discussion in the literature on European higher education policy discourse has mainly focused on the United Kingdom, and the wider context of the EU, as exemplified through the discourse surrounding the Bologna process. As part of this Bologna process many policy documents have been published, that enable various forms of qualitative analysis to uncover, for example, labels and constructs used to construct policy arguments. Some of these labels are more enduring than others, but what they have in common today is a general business metaphor, where the university has come to be seen as a production facility, where 
knowledge and graduates are the products. Universities today operate within what has been characterized as post-industrialism, globalization or postmodernity (Land, 2004). The labels that have gained prominence over the last two decades thus include "quality", "globalization", "knowledge", "diversity", and "employability".

In her commentary on the discourse used by the European Commission concerning higher education, Keeling (2006) points out that the Commission consistently depicts learning as a productive activity, through which students accumulate and generate knowledge, which results in both personal and social benefits. She finds that the Commission characterizes research outputs, such as "innovation", "technologies", "knowledge assets" and "intellectual property", as inherently measurable. Similarly, the concept of "quality" features frequently in Commission documents relating to the Bologna Process (Keeling, 2006). Saarinen (2008b), in an examination of a variety of EU documents, points to a use of such concepts of "quality", "student choice", and "higher education competitiveness" that presuppose without question the existence and validity of these language constructs. Given the powerful position of the Commission with respects to higher education policy across Europe, actors affected by such policies are simply not left the option of questioning the validity of the labels, but have to accept and adopt those labels in their own policies (Keeling, 2006). Worse still, as Peters (2001) points out, the language use in these policy texts, on the whole, do not operate with robust concepts of "learning" and "knowledge". Similar critiques have been made of the use of the construct of "employability", which typically ignores how social structures, such as gender, race, or social class, interact with labour market opportunities (Morley, 2001). Instead, policy assumes that "employability" is something the university can somehow fabricate. A similar criticism can be formulated regarding the tenuous links made in UK policy documents between "equality" and "diversity" (Archer, 2007).

Despite the apparent usefulness of discourse analysis, relatively few studies have conducted such detailed empirical analysis of policy documents (Saarinen, 2008a), much less any longitudinal analysis. Texts have mainly been approached in the literature in a static light, and with text being treated as illustrative of implemented policy. In other words, the existing literature mainly focusses on existing policy discourse, leaving aside any critical search for alternatives (Välimaa \& Hoffman, 2008). Discourse analysis may be particularly useful if conducted over a longer period of time, since this provides the possibility of determining shifts in discourse, rather than just statically analysing the current dominant discourse. Shifts in discourse are gradual (Leathwood \& O'Connell, 2003), and are typically not focused on any single label. Rather, the dominant higher education policy discourse should be seen a gradual accumulation of metaphors, images and labels, that redefine the shared understanding of what a university is and how it should be run. It is this gradual shift that we explore in this paper, in the context of Danish higher education policy.

\section{Critical Discourse Analysis: Theoretical Grounding and Method}

We base our analysis of the evolution of discourse on higher education policy on a method of critical discourse analysis (CDA). It is noteworthy that CDA is not just a method for analysing discourses, but is also to a degree a theory of scientific method (Fairclough, 2008). What is shared within the world of discourses is the constructivist epistemology. This means, in Kantian terms, that the world as it is (the thing itself) cannot be distinguished from 
how the world appears to us. It is more important how we perceive the world than whether this world exists with or without our perception. CDA distinguishes itself on this matter. CDA still maintains the constructivist epistemology, but this does not equal a relativistic approach (Johnstone, 2002). The goal for a critical discourse analysis is not just to describe the nature of different discourses and how these materialize and affect the world. It is also the goal for a critical discourse analysis to approach different discourses and challenge them. This means that discourses challenging the dominant discourse are just as important in a critical discourse analysis.

\section{The terminology of Siegfried Jäger}

In order to conduct a critical discourse analysis on educational policy in Denmark, the paper is based on the terminology of Siegfried Jäger and his approach to CDA. The reason for this choice is his macro-approach to discourses, which means that he is not interested in semantics at the micro-level, but rather sees discourses as the flow of text and speech through time (Fabech, 2008). Our analysis attempts to cover a sizable period of time (40 years), which makes this macroscopic approach particularly suitable.

The overall goal of our analysis is to create an overview in the myriad of discourses surrounding the topic at hand. Using Jäger's method of analysis, we look for structure within texts that will enable this analysis (Jäger, 1993, 2001). In his terminology texts consist of strands. A discourse strand is in Jäger's words a "thematically, uniform, discursive process", and it consists of several subtexts, that, as a whole, are one discourse. A discursive fragment is the smallest part of the Jäger terminology. It can be one whole text or a part of a text that concerns one specific theme and as such it is a part of a strand (Fabech, 2008). If one fragment leads back to more than one strand this is defined as an entanglement.

A discursive event influences the whole discourse. This event could be both a scientific report that, for example, presents new information about a specific subject, which then changes the understanding of this subject, or it could be a "real world event" as for example Chernobyl, which changed the discourse on atomic power.

Every discourse analysis is based on a reading of either one or a larger number of texts, often documents. In our case, we needed to identify discursive events that would serve as markers of potential change in higher education discourse. The research of this paper revolves around the six central government educational policy plans published between 1978 and 2007. In order to bring the analysis up to date, we added to these documents the current government plan papers published in October 2011 (government platform) and May 2012 (2020 economic plan). Our analysis thus covers almost 40 years (see Table 1). These documents, in that they were widely publicised and debated at the time of publication, and served as a guide for action for all actors involved in higher education, were chosen as important discursive events. These policy texts are viewed not only as the ideas of one small group of actors, in this case the government in power, but as a representation of current discourse, transferred between different actors at all levels. We focus on government papers as these are both the outcomes of a political process, and influence political discourse, and therefore are not "merely rhetoric", but shape "real policy" (Saarinen \& Ursin, 2012).

We used a macro-oriented method in which the reading of each plan is combined with Siegfried Jäger's tools for analysing macro-discursive processes. Rather than analysing the meaning of each word and sentence, and, for example, how these are supposed to affect the recipient, the objective of this paper is to provide an overview of the structure between the 
discourse strands and how these change over time (Jäger, 2001), as exemplified by each report.

Table 1 about here

To do this, a qualitative method was developed, which began with an inductive reading of each policy plan by five researchers, reading independently. The aim was to identify major strands. The research team would discuss each policy plan, and a number of keywords that lead back to each discourse strand were chosen. If a keyword was found in the text, and it fit the context of the argument, it could be seen as part of a discourse fragment. When such a discourse fragment was found in the beginning of a policy plan, it was typically a sign that the strand would play an important role in the whole policy plan. Other parameters that would point to the importance of each strand was the length of the discourse fragments, the number of keywords, and the number of discourse fragments that lead back to a certain strand. Whilst these are quantifiable parameters, they were always discussed in the context of the argument and the whole policy plan, so as to maintain a qualitative viewpoint in line with Jäger (1993), and the paper therefore contains no specific enumerations of the parameters.

\section{Analysis}

Five strands were identified and defined through the analysis, and will be discussed in this section: the economic strand; the global competition strand; the individualization strand; the democracy and citizenship strand; and the equality strand. The "life" of each strand is followed through six educational policy plans, one economic plan, and the government's platform of 2012, all made by the Danish government at that time. Each publication year is a reference point and each document a discursive event, that helps create a general idea of the development of each identified strand.

Based on the findings of the analysis, a model was produced which serves as a representation of the importance of the different strands in each policy plan. The purpose of this model is to give an overview of a quite extensive documentary analysis, so that the reader will be able to follow the development of each discourse strand and still have the whole discursive evolution in mind. The model consists of three different sizes of circles that are used to differentiate between the relative importance of each strand in each policy plan. It must be kept in mind that whilst this model could give the impression that the research was quantitative, it was not. The circle sizes are approximate representations of the important pieces of text that could be traced back to a certain discourse strand. This importance was determined on the basis of the before-mentioned different parameters and remains subjective, although some degree of triangulation was probably achieved due to the number of researchers involved in conducting the actual analysis (5). The horizontal lines are representations of the most important entanglements between discourse strands. These entanglements were not just entanglements between individual discourse fragments, but were present throughout the policy plan. 
Figure 1 about here

\section{The "economic" strand}

The economic strand is present in all the policy plans covered in the analysis. Therefore, the question is not whether the strand is present or not in each policy plan, but to what extent. The rationale in the economic strand is that education has a positive effect on the Danish economy. Students are seen as a resource (human capital) that enables future economic growth. The role of institutions of higher education is to produce this human capital.

U90 marks the first time that a coherent policy plan for education is presented. In U90 the economic rationales behind the expansion of the educational system in the post-war years are questioned. The focus in this strand is on the economic recession of the time (Ministry of Education, 1978: 86) but the economic strand has limited importance over-all. The U90 plan is still very much an extension of some of the reforms brought about following student riots across Europe in the late 1960s. Students at the time called for greater influence, greater involvement in governance, and a reform of education practice. We will return to this point later.

The economic strand is not very present either in U91. The policy plan emphasizes that even though there is a positive link between education and economic growth, the evidence for this link is not strong enough to become a guiding tool for political reforms (Ministry of Education, 1990: 76). In the policy plan from 1993 "Uddannelse til alle" (Education for everyone), there is only one significant part of the plan, where this strand is present. Here it is stressed that it is also important to take the economic factors into account, but this is due to external circumstances (Ministry of Education, 1993: 11).

In 1997, the Social Democratic led minority government launched a new educational policy plan with the title "Danmark som foregangsland (Denmark as a Role Model/ Pioneering Country)". In this policy plan, education is seen as an important part of the national economy (Regeringen, 1997: 5f). The plan emphasizes that it is necessary to make the educational sector as effective as possible. The importance of the economic strand is clear already in the first part of the policy plan:

“(...) Education is also a long-term public investment which affects the total growth in employment, productivity and wealth. Therefore, education is a very important part of the general economic policy" (Regeringen, 1997: 1, authors' translation).

This is further exemplified in chapter 3 of the policy plan (Regeringen, 1997: 27). This chapter is solely dedicated to explaining why education pays off economically both for the individual and the general public.

The economic strand is further present in the policy plan from 2002, "Better Education". What is noteworthy is how the economic strand is here entangled with the competition and individualization strand (as seen in the model). This makes it difficult to separate them. The following quote exemplifies this: 
"In the global economy, production and utilization of different knowledge is the key to increased growth, increased employment and greater welfare. The government's strategy of growth "Growth with Commitment" emphasizes an educational system in top class, a central argument to ensure growth and welfare. The competitiveness of Denmark will mostly depend on whether the educational system can live up to the demands of increased professional competence and standards, as well as professional development - in comparison with international, and not least EU, standards. The public sector and the business community largely depend on employees who are able to apply and facilitate information, and transform new information to innovation. Just as the underlying basis for an effective public sector are well-educated employees on all levels." (Regeringen, 2002: 9).

In the above quote, the overall setting is the global economy. In that setting, there is a need for increased professional competence. To get that, Denmark needs a "top class" educational system that provides an educated workforce able to compete in a global economy. Thus, education is now part of a larger political thinking. The entanglements of strands continues further in the educational plan "Danmarks strategi for livslang læring" (Denmark's strategy for lifelong learning) in 2007 and the economical "2020-plan" from 2012. In fact, the 2002 policy document appears to have been a relatively major discursive event, in that the discourse appears to have taken a new direction, which has been sustained during the last decade, and is still very much the dominant discourse today. This makes the contemporary Danish higher education discourse quite similar to that reported in the literature in the UK.

\section{The (global) “competition" strand}

The global competition strand's main argument is that education is necessary for Denmark in a more and more competitive global market. This strand is dominated by the same logic as the economic strand but focuses specifically on the notion of global competition, and national competitiveness. Thus, where the economic strand portrays the student as future human capital, the global competition strand emphasizes the economic role of the nation in an increasingly global economy. Here, the quality of education as compared to other nations is seen as important.

In 1978, globalization was not a very common term, which shows in the U90 policy plan. There is just one place in the policy plan (as far back as page 95), in which it is mentioned that education is important for the competitive power of a country. In U91 from 1990 and UTA from 1993 this strand does not hold a very prominent place either.

The most important discursive event in the global competition strand is the OECD report from 1997. This report concluded that the Danish educational system is very expensive compared to other countries and that the results of the system were lacking especially in the early school years. This critical view on the Danish educational system was essential for the new focus on global competition (Thomsen, 2008; Holm-Larsen, 1998; Blaksteen, 1997), and would also have a large impact on the general focus on economic rationales in Danish education policy as seen in the economic strand.

In the 1997 policy plan "Danmark som foregangsland" (Denmark as a Role Model/Pioneering Country), the title demonstrates this change perfectly. This is especially the case in the beginning of the policy plan, in which the purpose is presented: 
"Denmark's competitive power depends on whether the educational system will live up to the requirements of better standards, quality and progression - measured by international and EU-standards."

In the policy plans of 2002, 2007, and the government platform of 2011 and the 2020plan, this tendency continued with an entanglement of the economic strand, the global competition strand, and the individualization strand, being one of the main characteristics. For example, the 2007 policy plan "Denmark's strategy for lifelong learning" is a result of the Lisbon Treaty, and this strategy has the aim of making "Denmark a leading knowledge society in a globalized world". This strategy is part of an internationalization of the education system in Denmark, involving the introduction of the ECTS-system and the more international 7-point grading scale.

\section{The "individualization" strand}

The main rationale in the individualization strand is that education gives the individual more independence and freedom of choice, through the acquisition of greater knowledge. Education is seen as a way for the individual to climb the social ladder. One could see this strand as representative of the more classical liberal way of viewing higher education. The focus of policy is on the individual, and the competences acquired by the individual. The strand is most prominent in the U91 policy plan, and thus accompanies a period where the implementation of ideals later to be grouped under the heading New Public Management, was seen as a way to enhance individual choice in the educational sector (Ministry of Education, 1990: 31). The emphasis was on decentralization and power to the individual higher education institution, and the individual student:

"No-one believes anymore that micromanagement on the political level, or central administration, is the best form of governance. Local needs and opportunities, free choice for the users, and the motivation of employees [...] must play a bigger role in governance." (Ministry of Education, 1990, p. 31)

In later policy plans, the strand is entangled with the economic- and competition strand, which makes it difficult to register the strand by itself.

One of the large policy changes that occurred with U91 was the change from a centralized budget model, to the so-called taximeter system for Danish universities. Previously, budgeting had been centrally controlled, teacher-student ratios decided by government, and universities were granted annual lump-sum budgets. In 1994 a new system was introduced where each university would receive a per-student allocation, which could be spent much more freely, taking into account local needs. This was partly done in order to incentivize universities to increase the intake of new students. The intentions were thus similar to what was witnessed in the UK, where Labour wanted to raise the proportion of young gaining access to higher education. At the same time, the intention was to give more freedom of choice to the individual student, who for the first time is referred to as a customer:

"Through the taximeter system students will effectively become "customers", to which the institutions will be incentivized to provide the best possible teaching and education." (Ministry of Education, 1990, p. 32)

\section{The "democracy and citizenship" and "equality" strands}

The main rationale of the democracy and citizen strand is that the individual through 
education will become a democratic citizen who functions well in society. Contrary to the individualization strand, the aim is not to educate individuals so they can benefit personally from gaining employment with a higher pay, but rather that the individual becomes a "better" member of society. This strand shows itself throughout all of U90, the earliest of the texts examined, where education is supposed to deal with "every part of a person's life", but is also very present in UTA. The U90 plan can perhaps be seen as an extension of some of the reforms brought about following student riots across Europe in the late 1960s. Students at the time called for greater influence, greater involvement in governance, and a reform of education practice.

The equality strand is related, yet different. The argument in this strand is that education is way of achieving a more equal society in line with the social democratic ideals:

"One of the fundamental objectives of education policy is to achieve more equality, or said in another way, to level and reduce the big gaps and inequalities of society" (Ministry of Education, 1978, p. 11).

In later plans the democracy and formation strand is often present, but only mentioned as a digression, and the notion of equality is practically non-existent. The change in governments in Denmark can be seen as an explanation for the emergence of these strands in 1978 and 1993. At that point the government was led by the Social Democrats, and the discourse logically relates to their principles at the time. However, in 1997 and 2012 when the government was also socio- democratic, these strands disappeared almost completely. This could perhaps be explained by the over-all changes to the party's political stance, along the lines of the changes witnessed in the UK with New Labour (Leathwood \& O'Connell, 2003), but confirmation of this would require further analysis.

\section{Knowledge, competitiveness and the new economic discourse}

The increased influence of the economic and global competition strands could be seen as a manifestation and extension of the general political discourse, which in Denmark appears to have followed a similar trend to that discussed earlier in this paper. Notions of a knowledge economy and of the international competitiveness of nations have thus had an impact on the higher education discourse in the country. According to Pedersen (2011) the idea of a global economy evolved into an idea of competing nations, and this idea manifested itself in the Danish political discourse from around 1993 onwards. Our analysis largely confirms his analysis, where later plans are very much dominated by the economic and global competition strands. These later plans share the understanding that an improvement of the Danish competitiveness is a way to withstand globalization. To Pedersen (2011), this reflects a wider transition from the welfare state to the competitive state.

Since 1997 in particular, the arguments of Danish governments have had a lot in common with the economic rationales of the endogenous growth theory (Solow, 1991), and more generally neoclassical economics. Here, knowledge and human capital for the first time was seen as an integral part of a company's production facilities, and thereby also a way to raise growth rates. The importance of human capital and education is further increased as the service sector expands (Danmarks Statistik, 2001), and as the economy becomes increasingly knowledge based in Denmark. In reality, the proportion of the Danish economy related to the service sector has only marginally changed over the past forty years, but this has not prevented the dominant economic discourse from amplifying the importance of this sector. For example, the former Danish Prime Minister Anders Fogh Rasmussen said as follows in 
his speech at the annual opening of the Danish parliament in 2013:

"The prerequisite to ensure prosperity in the future is that we Danes are among the best educated in the world. Because knowledge and education is the path to growth" (Prime Minister's Office, 29.11.2013a)

On the other hand, the individuality strand is influenced by the rationales of New Public Management (Deem \& Brehony, 2005). The tendencies of New Public Management first appear in the 1980s Schlüter government with their U91 education plan, which focuses on the rationales of the market economy by optimizing and liberalizing industries and portions of management of the public sector (Thomsen, 2008). An example of this in the education sector is the introduction of the taximeter principles. The taximeter principles were to ensure a free educational choice and an economical reward to the institutions with the most graduates, and they thereby add market principles of competition between the institutions to the educational system. The general economic mood of the day thus heavily influences higher education policy discourse, regardless of whether the actors within higher education buy into this discourse or not (Trowler, 2001).

\section{Conclusion}

The discourse on Danish educational politics is fundamentally different now compared to the late 1970s. Whereas the first policy plans, especially U90 and UTA, focused on equality and forming the democratic and enlightened citizen, later plans focus mainly on the economic benefits of education to the wider economy. The economic strand has been present in all the educational policy plans - especially from 1997 and onwards. But from here, the economic strand is the hugely dominant basis together with the competition strand and the individual strand. In other words, these different strands are entangled, which means, that it is difficult to separate the strands and identify them for themselves. The rationale presented in the discourse is therefore muddled, which may help explain why some scholars have found political arguments to be fundamentally flawed in modern higher education policy discourse (Peters, 2001), and may also explain why academics tend to reject much of this discourse (Trowler, 2001).

There are many possible explanations for this development. One possible explanation is the growing popularity during the last twenty years of the idea of a competitive global knowledge economy (Välimaa \& Hoffman, 2008), which has firmly established itself in Danish educational politics. As a consequence of this, the supply of educated labour has been seen as a way to sustain economic growth in later years. Although economic theory in general suggests a correlation between economic growth and a more educated population, at a certain educational level, this correlation becomes less clear, and in a time of financial crisis the strategy of increasing the supply of graduates seems questionable. The private sector must expand if all new graduates are to get a job and there is debate about whether those who have just finished their education are subject to unemployment. The danger of unemployment among new graduates is by some experts referred as the danger of an "academic proletariat".

As described in the analysis, the Danish educational system has undergone a continuous transformation towards New Public Management ideals. One new example of this is shown in the latest Finance Bill, which proposes that universities should receive less 
money per student, in order to educate more efficiently. This strategy could be problematic if the long-term goal is to increase the quality of the Danish educational system. The quality of the Danish educational system has been a topic for discussion in recent years and as a consequence, the Danish government has recently set up a commission whose mandate is to evaluate this question.

Though there are several questionable aspects to the current rationales behind the educational discourse, we also acknowledge that there is a lack of concrete alternatives. Whether older logics such as the democracy and formation strand and the equality strand have something different to offer is up for discussion. Overall, economy and education are increasingly interconnected in Danish educational politics. Especially since 2002, the strands become more and more linked. This connection consists of a bidirectional relationship, where economy influences the educational system and where the rationales of the educational system concerning development, education and knowledge expand and influence other aspects of society - in particular the economy. These observations are in accordance with Lieberkind (2010), who describes this link as the key educative discourse in Denmark. This expansion of the rationales of education has become a dogma that applies to all of society. Lifelong learning becomes a common responsibility to secure the national economy and the competitive power of the nation when facing the global economy.

\section{References}

Archer, L. 2007. "Diversity, equality and higher education: a critical reflection on the ab/uses of equity discourse within widening participation." Teaching in higher Education, 12(5-6), 635-653.

Blaksteen, M. 1997. "Skolen i årets løb” in Uddannelseshistorie. Copenhagen: Selskabet for skole- og uddannelseshistorie.

Danmarks Statistik, 2001. 50-års oversigten. Copenhagen: Danmarks Statistik.

Deem, R., \& Brehony, K. J. 2005. "Management as Ideology: The Case of 'New Managerialism' in Higher Education." Oxford Review of Education, 31(2), 217-235.

Fabech, Sidsel Grøn. 2008: "Diskurser er som en flod af viden, der lфber gennem tiden.”Working Paper, Copenhagen Business School.

Fairclough, N. 1993. "Critical discourse analysis and the marketization of public discourse: The universities". Discourse \& Society, 4(2), 133-168.

Fairclough, Norman. 2008: "Kritisk diskursanalyse." Translated and edited by Elisabeth Halskov Jensen. Copenhagen: Hans Reitzels Publishing.

Foucault, M. 1972. “The archeology of knowledge.” London: Tavistock.

Giddens, A. 1984. "The constitution of society”. Cambridge: Polity Press.

Holm-Larsen, S. 1998: "Skolen i årets løb” in Uddannelseshistorie. Copenhagen: Selskabet for skole- og uddannelseshistorie. 
Johnstone, Barbara. 2002. "Discourse Analysis.” Malden, MA: Blackwell Publishers Inc.

Jäger, S. 1993. “Kritische Diskursanalyse: Eine Einführung“. Edition DISS: Duisburg

Jäger, S. 2001. "Discourse and knowledge: Theoretical and methodological aspects of a critical discourse and dispositive analysis" in: Methods of Critical Discourse Analysis, edited by Wodak, R. and Meyer, M. London: SAGE.

Keeling, R. 2006. "The Bologna Process and the Lisbon Research Agenda: the European Commission's expanding role in higher education discourse." European Journal of Education, 41(2), 203-223.

Land, R. 2004. "Educational development: Discourse, identity and practice." McGraw-Hill International.

Leathwood, C. \& O'Connell, P. 2003. "'It's a struggle': the construction of the 'new student' in higher education." Journal of Education Policy, 18:6, 597-615.

Lieberkind, J. 2010. "Det edukative: Emile Durkheim og den moderne padagogiseringstendens." Unpublished PhD thesis. Aarhus University, Denmark.

Ministry of Education. 1978. "U90 - samlet uddannelsesplanloegning frem til 90'erne."

Ministry of Education. 1990. "U91 - Det nye mønster i dansk uddannelses- og forskningspolitik."

Ministry of Education. 1993. "Uddannelse til alle - undervisningsministerens redegфrelse til Folketinget."

Ministry of Education. 2007. "Danmarks strategi for livslang laering."

Morley, L. 2001. "Producing new workers: quality, equality and employability in higher education." Quality in Higher Education, 7(2), 131-138.

Olssen, M. \& Peters, M. A. 2005. "Neoliberalism, higher education and the knowledge economy: from the free market to knowledge capitalism." Journal of Education Policy, 20:3, 313-345-

Pedersen, Ove K. 2011. “Konkurrencestaten”. Copenhagen: Hans Reitzels Publishing.

Peters, M. 2001. "National education policy constructions of the 'knowledge economy': towards a critique." The Journal of Educational Enquiry, 2(1), 1-22.

Prime Minister's Office. "Statsminister Anders Fogh Rasmussens tale ved Folketingets åbning tirsdag den 1. oktober 2002." Internet: http://www.stm.dk/_p_7367.html, 29.11.2013a.

Regeringen (The Danish government). 1997. "Danmark som Foregangsland." 
Regeringen (The Danish government). 2002."Bedre Uddannelser."

Regeringen (The Danish government). 2012b. "Danmark i arbejde - udfordringer for dansk фkonomi mod 2020."

Saarinen, T. 2008a. "Position of text and discourse analysis in higher education policy research." Studies in Higher Education, 33(6), 719-728.

Saarinen, T. 2008b. "Persuasive presuppositions in OECD and EU higher education policy documents." Discourse Studies, 10 no. 3: 341-59.

Saarinen, T., \& Ursin, J. (2012). "Dominant and emerging approaches in the study of higher education policy change". Studies in Higher Education, 37(2), 143-156.

Solow, Robert M. 1991. "The Rate of Return and the Rate of Interest." Stockholm: Almqvist \& Wiksell International.

Thomsen, J. P. 2008. "Social differentiering og kulturel praksis på danske universitetsuddannelser." Unpublished PhD thesis. Roskilde University, Denmark.

Tight, M. 2003. “Researching higher education.” McGraw-Hill International.

Trowler, P. 2001. "Captured by the Discourse? The Socially Constitutive Power of New Higher Education Discourse in the UK.” Organization, 8(2), 183-201.

Välimaa, J., \& Hoffman, D. 2008. "Knowledge Society Discourse and Higher Education." Higher Education, 56(3), 265-285. 


\begin{tabular}{|c|c|c|}
\hline $\begin{array}{l}\text { Publication } \\
\text { Year }\end{array}$ & Title & $\begin{array}{l}\text { Approximate Page } \\
\text { and Word Count }\end{array}$ \\
\hline 1978 & $\begin{array}{l}\text { U90 - Samlet } \\
\text { uddannelsesplanlægning frem til } \\
\text { 90'erne (Collective education } \\
\text { planning until the 1990s) }\end{array}$ & $\begin{array}{l}295 \text { pages excl. } \\
\text { appendices } \\
85^{\prime} 000 \text { words }\end{array}$ \\
\hline 1990 & $\begin{array}{l}\text { U91 - Det nye mønster I dansk } \\
\text { uddannelses- og } \\
\text { forskningspolitik (The new } \\
\text { pattern in Danish education and } \\
\text { research policy) }\end{array}$ & $\begin{array}{l}139 \text { pages } \\
29^{\prime} 000 \text { words }\end{array}$ \\
\hline 1993 & $\begin{array}{l}\text { Uddannelse til alle (Education } \\
\text { for all) }\end{array}$ & $\begin{array}{l}30 \text { pages excl. } \\
\text { appendices } \\
4^{\prime} 000 \text { words }\end{array}$ \\
\hline 1997 & $\begin{array}{l}\text { Danmark som foregangsland } \\
\text { (Denmark as exemplary country) }\end{array}$ & $\begin{array}{l}94 \text { pages } \\
21 \text { '000 words }\end{array}$ \\
\hline 2002 & $\begin{array}{l}\text { Bedre uddannelse (Better } \\
\text { education) }\end{array}$ & $\begin{array}{l}72 \text { pages } \\
16 \text { ' } 000 \text { words }\end{array}$ \\
\hline 2007 & $\begin{array}{l}\text { Danmarks strategi for livslang } \\
\text { læring (Denmark's strategy for } \\
\text { lifelong learning) }\end{array}$ & $\begin{array}{l}34 \text { pages } \\
\text { 7'200 words }\end{array}$ \\
\hline 2011 & $\begin{array}{l}\text { Regeringsgrundlaget } \\
\text { (Government platform) }\end{array}$ & $\begin{array}{l}80 \text { pages } \\
26 \text { ' } 600 \text { words }\end{array}$ \\
\hline 2012 & $\begin{array}{l}\text { Danmark i arbejde - } 2020 \text { planen } \\
\text { (Denmark at work - the } 2020 \\
\text { plan) }\end{array}$ & $\begin{array}{l}128 \text { pages } \\
38^{\prime} 000 \text { words }\end{array}$ \\
\hline
\end{tabular}

Table 1. Selected Danish higher education policy documents (authors' translations) 

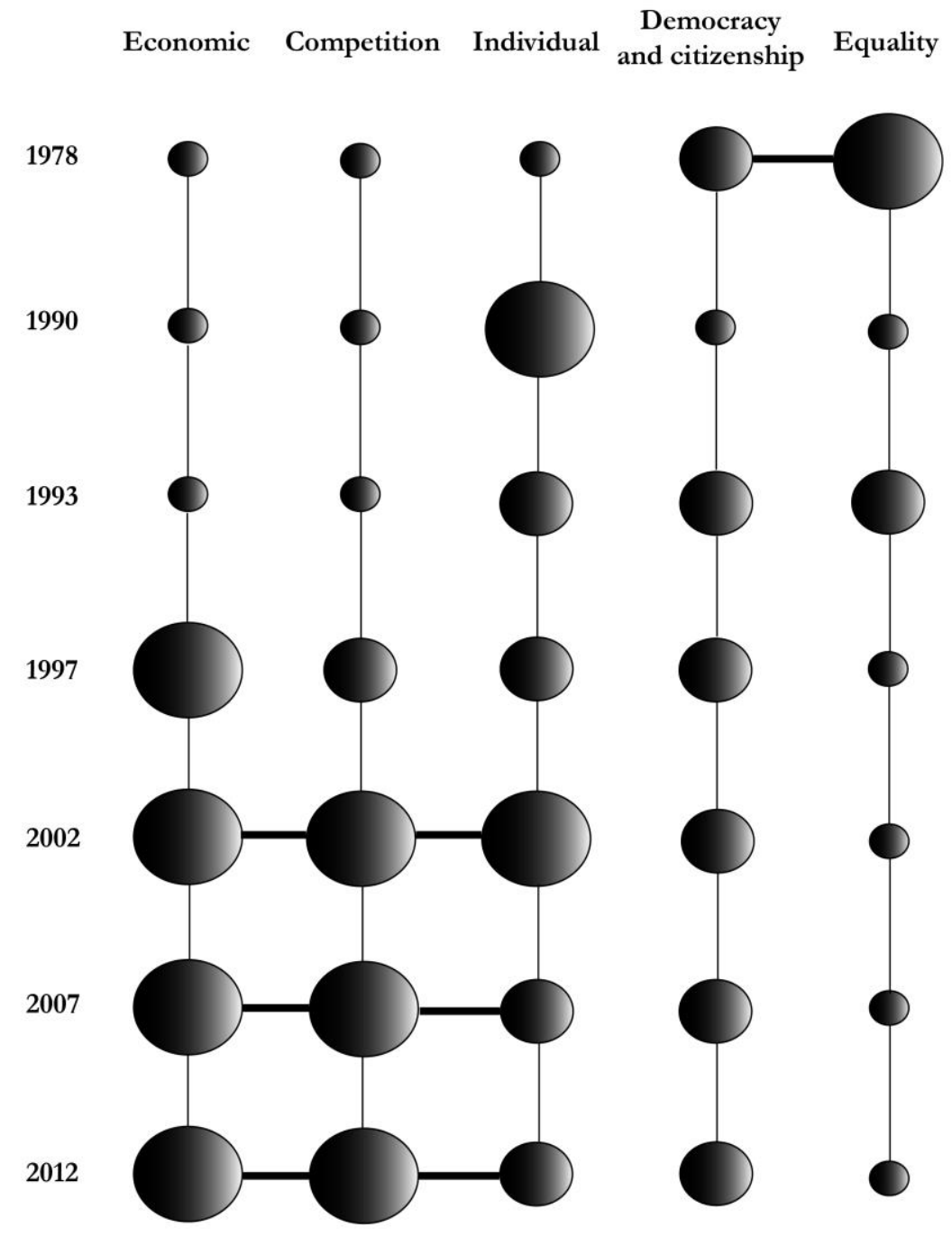

Figure 1. Discourse strands in Danish higher education policy documents 